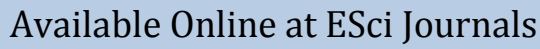 \\ International Journal of Phytopathology
}

ISSN: 2305-106X (Online), 2306-1650 (Print)

http://www.escijournals.net/phytopathology

\section{PATHOGENICITY OF FUNGI ASSOCIATED WITH POST-HARVEST DETERIORATION OF TWO COCOYAM VARIETIES (C. ESCULENTA VAR. ANTIQUORUM AND $C$. ESCULENTA VAR. ESCULENTA) SCHOTT IN SOME PARTS OF JOS.}

\author{
Pandukur S. Garba, Plangnan G. Alexander, Amienyo C. Ada \\ Department of Science Laboratory Technology and Department of plant Science and Technology, Faculty of Natural \\ Sciences, University of Jos, Jos, Nigeria.
}

\begin{abstract}
A B S T R A C T
An investigation was carried out to test for the pathogenicity of fungi associated with the deterioration of two varieties of cocoyam corms and cormels. Fifty (50) infected corms and cormels with symptoms of post-harvest rots were purchased from six markets within Plateau Central zone and analyzed. Eleven (11) fungal isolates were implicated in the deterioration of the two varieties of the cocoyam (C. esculenta var. antiquorum and C. esculenta var. esculenta) corms and cormels and were identified as; Alternaria alternata, Fusarium oxysporum, Verticilium lateritium, Botryodiplodia theobramae, Colletotrichum coccoides, Phythium myriotylum, Fusarium verticillioides, Rhizopus stolonifer and Geotricum candidum. The result showed that all these fungi were highly virulent on the two varieties, except $C$. coccoides, $F$. verticillioides and A. alternata which did not caused rot on $C$. esculenta var. esculenta. Meanwhile, the fungus Rhizopus stolonifer induced the highest percentage mean area of rot $(39.96 \%)$ followed by Alternaria alternata (39.36\%), Phythium myriotylum (38.60\%), Botryodiplodia theobromae (36.89\%) while the least was Fusarium oxysporium (27.66\%) in C. esculenta var. antiquorum. The study further revealed the highest rot induced on C. esculenta var. esculenta by the isolated fungi, V. lateritium (42.45\%) followed by G. candidum (34.29\%), F. oxysporum (27.96\%) while the least was Rhizopus stolonifer (20.33\%). The result also showed that C. esculenta var. esculenta was comparatively more susceptible or significant $(\mathrm{P}<0.05)$ to the fungus $V$. lateritium since it showed a greater (extensive) mean percentage area of rots of $42.45 \%$ on the corms and cormels than on C. esculenta var. antiquorum with $36.01 \%$.
\end{abstract}

Keywords: Pathogenicity, Fungi, Post-harvest, Cocoyam varieties, Deterioration, Jos.

\section{INTRODUCTION}

Cocoyam (Colocasia esculenta L. Schott) belongs to the genus Colocasia, and generally comprised of a large spherical corm (swollen underground storage stem), from which a few large leaves emerge (Onwueme, 1999). It refers to the two members of the Araceae family that are staple foods for many people in developing countries in Africa, Asia and the Pacific namely, C. esculenta var. esculenta and C. esculenta var. antiquorum (L) Schott (Aguegui et al., 1992). It is an important tropical tuberous crop, and a traditional starch staple food for millions of people in the developing countries of the tropics, subtropics, Pacific Islands, West Indies and the

\section{* Corresponding Author:}

Email: psgpan1@yahoo.com

(c) 2016 ESci Journals Publishing. All rights reserved.
Mediterranean (Onwueme, 1999).

Nutritionally, cocoyam is rich in carbohydrates (13$29 \%)$, vitamins and minerals. It also contains proteins (1.4-3.0\%) the leaves are rich sources of vitamin B6, vitamin C, niacin, thiamin (B1) and riboflavin (B2) (Maduewesi and Onyike, 1981). They are also rich in minerals such as iron, phosphorus, zinc, potassium, copper and manganese. In addition to starch, the corms and cormels are good sources of dietary fiber $(0.60$ 1.18) as well as oxalic acid, which cause serious irritation when raw corms come in contact with the skin (Zuhair and Hunter, 2000). The high digestibility and the very small size of the starch granules make cocoyam a very suitable base for baby's foods (Offei et al., 2004). Although cocoyam is composed predominantly of starch, it is next only to certain varieties of yam in crude protein 
content among root crops (Uguanyi and Obeta, 1996). Production of cocoyam has not been given priority attention in many countries, probably because of its inability to earn foreign exchange, as well as its unacceptability by the high income countries for both consumption and other purposes (Eze and Okorji, 2003). Post-harvest loss of root and tuber crops has been a very serious problem to farmers as more than $40 \%$ of their harvest may be lost because of decay (Olurinola et al., 1992). Studies have shown that fungal rot is the greatest cause of root and tuber loss in storage (IITA, 1993). The principal species of microorganisms associated with cocoyam rot in Nigeria include Aspergillus flavus, Penicillium digitatum, Botryodiplodia theobromae, Sclerotia rolfsii, Fusarium solani and Erwinia carotovora, these fungi were reported to be virulent to four cultivars of Colocasia esculenta, causing rot of cocoyam in several parts of southern Nigeria (Brunt et al., 2001).

A challenging situation arose in Mangu and Bokkos zone (Northern central part of Plateau State of Nigeria) since the past ten years following the outbreak of devastating diseases affecting tissues of cocoyam corms and cormels in the areas. Due to the devastating nature of these diseases and the serious threat to food security and income earnings, there have been calls from consumers, organizations and members of the public to scientists to identity the cause of these diseases and advance measures for its control. In line with the above calls, this research was undertaken to isolate and identify the casual agents of these diseases in relation to their pathogenicity on fresh corms and cormels of the two varieties with a view to advancing measures of control in subsequent work.

\section{MATERIALS AND METHODS}

Sample collection: Fifty (50) rotten and healthy corms and cormels of the two varieties of cocoyam (Colocasia esculenta var. esculenta and Colocasia var. antiquorum (L) schott) showing symptoms of post-harvest rots were purchased randomly from six (6) markets in two (2) local government areas (Mangu and Bokkos) that are major producers of cocoyam in Plateau state.

Isolation of Fungal Pathogens from Rotten Cocoyam corms and cormels: The isolation of fungal pathogens was done using the methods of Clement and Voros (1974); Aggarawal et al. (1990). Twelve (12) diseased samples each of the two varieties collected were surface sterilized with one per cent (1\%) sodium hypo chloride $(\mathrm{NaOCl})$ solution for one minute to remove surface contaminants after washing off soil and roots debris or extraneous materials from the corms and cormels. This was followed by three successive rinses in distilled water. Rotten corms and cormels showing inherent diseased symptoms of soft or white, black, brown and hard rots were removed as diseased samples. They were later categorized with different codes as soft rot (SR), brown rot (BR) and hard or dry rot (HR) respectively for easy identifications. The diseased samples will be used for the isolation of fungal pathogens.

Diseased portions or areas where the presence of rots was apparent were cut out using sterile kitchen knife and sliced into small pieces (1-2mm diameter) separately according to the diseased symptoms earlier observed physically on the corms and cormels. The cormel piece were placed on sterile paper towels in a Laminar Air flow Hood chamber for 10 minutes to dry and then placed on SPDA (streptomycin-based potato dextrose agar) plates using a sterile inoculating loop. The plates were incubated at $27^{\circ} \mathrm{C}$ for seven days and then examined daily for the development of fungal growth. Each experiment was replicated six (6) times for each of the identified diseased symptoms.

Sub culturing/Purification and Identification of Isolated Fungi: When growth has established, subcultures were prepared using inocula from the different organisms in the mixed cultures to obtain a pure culture, this was done by transferring hyphal tips from the colony edges of the mixed cultures to fresh plates of sPDA using flame-sterilized blades. After subculturing the plates were incubated at $27^{\circ} \mathrm{C}$ until pure cultures were obtained. Seven day old cultures of the fungi from the two varieties of the cocoyam were used according to their diseased symptoms. Wet mount of the pure cultures were prepared and mounted on a drop of lacto phenol in cotton blue stain and placed at the center of a clean slide. The resulting pure cultures were used for characterization and subsequent identification of the fungi isolates with the aid of a compound microscope and a bi-nuclear (in order to get a very clear sporangia and sporangiospores) at $\times 40$ and $\times 100$ objectives for every diseased symptom identified physically and structures which include micro and macro conidia, sporangia, septation etc. where observed and compared with standard published identification guides by Domsch et al. (1980), Olutola et al. (2000), Samson et al. (1995), Ellis, 2005b and Ellis et al. (2007). 
Pathogenicity Test: This test was conducted using the 15 and 11 pure cultures of the fungi isolated from the markets on the corms and cormels of C. esculenta var. antiquorum and C. esculenta var. esculenta respectively to determine the ability of each fungal isolates to cause disease on fresh healthy cocoyam corms and cormels. Fresh healthy whole corms and cormels of the two cocoyam varieties were first washed with tap water and there after dipped completely in $1 \%$ sodium hypochlorite $(\mathrm{NaOCl})$ solution. The corms and cormels were placed on sterile paper towels and allowed to dry for twelve (12) minutes in a Laminar Air flow cabinet. Sterile cork borer ( $3 \mathrm{~mm}$ diameter) was used to bore holes in the cocoyam corms and cormels. The parts of the corms and cormels which were bored out at each point were kept in sterile Petri dishes. An agar blocks measuring $4 \mathrm{~mm}$ by $4 \mathrm{~mm}$ from growing cultures of each test isolates (15 and 11 pure cultures of the fungi isolated from the markets on the corms and cormels of $C$. esculenta var. antiquorum and C. esculenta var. esculenta respectively) were inoculated into the holes made with the aid of another cork borer $(4 \mathrm{~mm}$ diameter). After the inoculation, the parts of the corms and cormel bore out were carefully replaced and sealed with sterile Vaseline to prevent contamination and labeled accordingly. A control experiment which bore no isolate was also set-up (inoculated with $1 \mathrm{ml}$ of sterile distilled water). After inoculating the entire test isolates into their respective healthy corms and cormels, all the cormels and corms were incubated for 14 days in a humidity chamber at room temperature $\left(25^{\circ} \mathrm{C}\right)$. The corms and cormels were examined daily for evidence of rot such as softening, discoloration and offensive odour. At the end of the 14 days incubation period, the corms and cormels were carefully cut open along the line of inoculation to expose the regions of the corms and cormels which were then examined for rot. Where positive, the length and girth of the rot area and those of the entire corms and cormels shown were measured and recorded.

Data Analysis: Data obtained by measurement of radial diameter was analyzed using analysis of variance (ANOVA) and the rate of growth of inoculated corms and cormels of each variety and the means were separated with Duncan's Multiple Range Test (DMRT).

\section{RESULTS}

Results of the study showed that only six (6) out of the fifteen (15) fungal isolates were implicated in the rotting of both varieties of the cocoyam corms and cormels (C. esculenta var. esculenta and C. esculenta var. antiquorum). These fungi were identified as, Fusarium oxysporum, Verticilium lateritium, Botryodiplodia theobramae, Phythium myriotylum, Rhizopus stolonifer and Geotricum candidum. Meanwhile, three (3) fungal isolates (Alternaria alternata, Colletotrichum coccoides and Fusarium verticillioides) were only virulent on $C$. esculenta var. antiquorum. The result showed that all these fungi were highly virulent on the two varieties, except $C$. coccoides, $F$. verticillioides and A. alternata which did not caused rot on C. esculenta var. esculenta. These fungal isolates only caused about 00.02\% percentage mean area of rots on this cocoyam variety (Tables 2). The laboratory investigation showed that disease symptoms first appeared or developed two days after inoculation on the corms and cormels. The most virulent among the nine tested fungi was $A$. alternata followed by $R$. stolonifer with rot incidences of $69.90 \%, 69.01 \%$ in C. esculenta var. antiquorum (Table 1) respectively. Meanwhile, V. lateritium was virulent in C. esculenta var. esculenta followed by $G$. candidum with $78.20 \%$ and $64.80 \%$ (Table 2) respectively. While the least virulent on $C$. esculenta var. esculenta were $F$. oxysporum and $R$. stolonifer with rot occurrences of $46.30 \%$ and $41.10 \%$ respectively. They produced symptoms, which closely resembled those observed from the infected corms and cormels of the two cocoyam varieties from the six markets. The degree of susceptibility of these two varieties differed significant $(\mathrm{P}<0.05)$. Further analysis using the Duncan's Multiple Range Test (DMRT), also showed there was a significant $(\mathrm{P}<0.05)$ difference between the two cocoyam varieties in terms of their percentage mean area of rot as the period of incubation increased (Tables 1 and 2). The rots due to A. alternata, $B$. theobromae, $V$. lateritium, Geotrichum candidum, Phythium myriotylum, C. coccoides, Fusarium oxysporum, $F$. verticillioides and Rhizopus stolonifer were extensive, invaded the entire cocoyam corms and cormels' bark, resulting in complete maceration of the cocoyam tissues after (14) days (Tables 1 and 2). The rate of growth varied significantly $(\mathrm{P}<0.05)$ at some days but not in others as elaborated in the mean separation tables (1 and 2). 
Int. J. Phytopathol. 05 (01) 2016. 29-34

Table 1. Pathogenicity of 9 Isolated Fungi showing the Mean Percentage Area of Infected corms and cormels of var. antiquorum.

\begin{tabular}{llllllll}
\hline & \multicolumn{7}{c}{ Period of incubation (Days) } \\
\hline FUNGI & 2 & 4 & 6 & 8 & 10 & 12 & 14 \\
\hline Alternaria alternata & $4.78^{\mathrm{a}}$ & $13.23^{\mathrm{e}}$ & $28.37^{\mathrm{h}}$ & $39.15^{\mathrm{i}}$ & $58.60^{\mathrm{k}}$ & $61.65^{\mathrm{L}}$ & $69.77^{\mathrm{L}}$ \\
Botrydiplodia theobromae & $5.43^{\mathrm{b}}$ & $11.20^{\mathrm{d}}$ & $29.65^{\mathrm{h}}$ & $33.00^{\mathrm{i}}$ & $56.10^{\mathrm{k}}$ & $60.37^{\mathrm{L}}$ & $62.50^{\mathrm{L}}$ \\
Colletotrichum coccoides & $9.73^{\mathrm{c}}$ & $16.58^{\mathrm{f}}$ & $31.20^{\mathrm{i}}$ & $38.70^{\mathrm{i}}$ & $41.77^{\mathrm{j}}$ & $50.13^{\mathrm{k}}$ & $54.72^{\mathrm{k}}$ \\
Fusarium verticillioides & $5.05^{\mathrm{b}}$ & $11.58^{\mathrm{d}}$ & $23.63^{\mathrm{h}}$ & $34.22^{\mathrm{i}}$ & $39.12^{\mathrm{i}}$ & $43.20^{\mathrm{j}}$ & $51.05^{\mathrm{k}}$ \\
Fusarium oxysporum & $4.58^{\mathrm{a}}$ & $17.23 \mathrm{~g}$ & $21.07^{\mathrm{h}}$ & $28.27^{\mathrm{h}}$ & $36.05^{\mathrm{i}}$ & $40.12^{\mathrm{j}}$ & $46.27^{\mathrm{j}}$ \\
Geotricum candidum & $5.20^{\mathrm{a}}$ & $13.03^{\mathrm{e}}$ & $30.17^{\mathrm{i}}$ & $38.53^{\mathrm{i}}$ & $47.05^{\mathrm{j}}$ & $52.03^{\mathrm{k}}$ & $61.22^{\mathrm{L}}$ \\
Phythium myriotylum & $9.78^{\mathrm{c}}$ & $20.00^{\mathrm{h}}$ & $34.10^{\mathrm{i}}$ & $39.90^{\mathrm{i}}$ & $41.05^{\mathrm{j}}$ & $56.72^{\mathrm{k}}$ & $68.60^{\mathrm{L}}$ \\
Rhizopus stolonifer & $9.73^{\mathrm{c}}$ & $20.02^{\mathrm{h}}$ & $34.27^{\mathrm{i}}$ & $41.35^{\mathrm{j}}$ & $48.23^{\mathrm{j}}$ & $57.05^{\mathrm{k}}$ & $69.07^{\mathrm{L}}$ \\
Verticillium lateritium & $4.83^{\mathrm{a}}$ & $11.68^{\mathrm{d}}$ & $29.80^{\mathrm{h}}$ & $37.72^{\mathrm{i}}$ & $48.08^{\mathrm{j}}$ & $57.87^{\mathrm{k}}$ & $62.05^{\mathrm{L}}$
\end{tabular}

The values are mean SD of six determinations. Means followed by the same superscript letter within columns are not significantly ( $\mathrm{P}>0.05$ ) different as assessed by Duncan Multiple Test (DMRT).

Table 2. Pathogenicity of Nine (9) Isolated Fungi Showing the Mean Percentage Area of Infected corms and cormels of C. esculenta var. esculenta.

\begin{tabular}{llllllll}
\hline & \multicolumn{7}{c}{ Period of incubation (Days) } \\
\hline FUNGI & 2 & 4 & 6 & 8 & 10 & 12 & 14 \\
\hline Botrydiplodia. theobromae & $9.40^{\mathrm{h}}$ & $6.07^{\mathrm{e}}$ & $13.85^{\mathrm{j}}$ & $18.32^{\mathrm{L}}$ & $34.07^{\mathrm{n}}$ & $46.23^{\mathrm{o}}$ & $53.08^{\mathrm{p}}$ \\
Fusarium oxysporum & $2.07^{\mathrm{a}}$ & $6.72^{\mathrm{e}}$ & $14.72^{\mathrm{k}}$ & $26.07^{\mathrm{m}}$ & $31.38^{\mathrm{n}}$ & $51.05^{\mathrm{p}}$ & $63.70^{\mathrm{q}}$ \\
Geotricum candidum & $5.22^{\mathrm{d}}$ & $13.05^{\mathrm{j}}$ & $20.25^{\mathrm{m}}$ & $38.72^{\mathrm{n}}$ & $41.03^{\mathrm{o}}$ & $57.05^{\mathrm{p}}$ & $64.72^{\mathrm{q}}$ \\
Phythium myriotylum & $4.15^{\mathrm{c}}$ & $9.05^{\mathrm{h}}$ & $15.28^{\mathrm{k}}$ & $26.80^{\mathrm{m}}$ & $31.05^{\mathrm{n}}$ & $47.60^{\mathrm{o}}$ & $51.02^{\mathrm{p}}$ \\
Verticillium. lateritium & $8.27^{\mathrm{g}}$ & $15.68^{\mathrm{k}}$ & $29.17^{\mathrm{m}}$ & $48.03^{\mathrm{o}}$ & $53.83^{\mathrm{p}}$ & $64.07^{\mathrm{q}}$ & $78.08^{\mathrm{r}}$ \\
Rhizopus stolonifer & $3.73^{\mathrm{b}}$ & $7.77^{\mathrm{f}}$ & $11.05^{\mathrm{i}}$ & $17.75^{\mathrm{L}}$ & $28.52^{\mathrm{m}}$ & $32.45^{\mathrm{n}}$ & $41.03^{\mathrm{o}}$ \\
Colletotrichum coccoides & $0.01^{\mathrm{z}}$ & $0.02^{\mathrm{z}}$ & $0.01^{\mathrm{z}}$ & $0.01^{\mathrm{z}}$ & $0.02^{\mathrm{z}}$ & $0.01^{\mathrm{z}}$ & $0.02^{\mathrm{z}}$ \\
Alternaria alternata & $0.02^{\mathrm{z}}$ & $0.02^{\mathrm{z}}$ & $0.01^{\mathrm{z}}$ & $0.01^{\mathrm{z}}$ & $0.02^{\mathrm{z}}$ & $0.02^{\mathrm{z}}$ & $0.01^{\mathrm{z}}$ \\
Fusarium verticillioides & $0.02^{\mathrm{z}}$ & $0.01^{\mathrm{z}}$ & $0.02^{\mathrm{z}}$ & $0.02^{\mathrm{z}}$ & $0.02^{\mathrm{z}}$ & $0.01^{\mathrm{z}}$ & $0.02^{\mathrm{z}}$ \\
\hline
\end{tabular}

The values are mean SD of six determinations. Means followed by the same superscript letter within columns are not significantly $(\mathrm{P}>0.05)$ different as assessed by Duncan's multiple range tests.

Two (2) days after inoculation, A. alternata and $R$. Stolonifer at first showed a white floccos hyphae maturation becoming rapidly black and rampant. $V$. lateritium, G. candidum, B. theobromae and F. oxysporum produces watery freely, smooth walled, white mycelium, which increases in sizes very rapidly by centrifugal growth and produced concentric colour pattern of white at periphery, becoming grey to dark grey or dark brown with some pinkish undifferentiated hyphae on the corms and cormels, and at maturation gives an offensive and sour odor. Corms and cormels inoculated with $C$. coccoides developed soft and brown rot with blue substances on the bark and tissues. Ten days after inoculation it showed a plain colonies, white grayish to olive mycelium with an aerial hyphae. Phythium myriotylum and $V$. lateritium almost had the same characteristics symptoms. The corms and cormels skin splits and creamy brown to dark mould developed on the exposed flesh, while Alternaria alternata and Rhizopus stolonifer showed characteristics copious production of dark olive-green black spores to dark grey cobwebby growth.

\section{DISCUSSION}

Pathogenicity tests on the two susceptible healthy cocoyam varieties (C. esculenta var. esculenta and $C$. esculenta var. antiquorum) using nine (9) of the fungal isolates, showed that only P. myriotylum, V. lateritium, $G$. candidum, $R$. stolonifer, C. coccoides, B. theobramae, F. oxysporum, $F$. verticuloides and A. alternata incited or were pathogenic on both the test cocoyam varieties and not by a complex of organisms as suggested by earlier workers. Contrary to the results obtained by Anukworji et al. (2013), Verticillium lateritium was the most virulent followed by $B$. theobromae on the two varieties 
of the cocoyam corms and cormels after pathogenicity test in this study. The fungi A. alternata, F. verticillioides and $C$. coccoides, were only virulent on $C$. esculenta var. antiquorum not on C. esculenta var. esculenta.

Furthermore, new species of fungi (Verticillium lateritium and Collectotrichum coccoides) were isolated on C. esculenta var. antiquorum in addition to Corticum rolfsii isolated by other researchers in a similar study on cocoyam rot caused by fungi. This observation also indicated that the difference in the environment and location or sites could have been some of the major reasons that had influenced the process of an epidemic, or have the capacity to induce or retard it. This result corroborates the findings of earlier researchers like the work of Chiejina and Ugwuja (2013) on the Incidence of Phytophthora Leaf-Blight disease of cocoyam in Nsukka area of South Eastern Nigeria and Agrios (2005) on plant pathology. Eze and Maduewesi, 1990 also reported the involvement of the test fungi (A. niger and Fusarium spp.) in pathogenesis of cocoyam.

Moreover, C. esculenta var. esculenta cocoyam variety resisted three (3) out of the nine (9) rot causing fungi isolated after pathogenicity test from the sampled markets which were virulent on $C$. esculenta var. antiquorum. The fungi are: A. alternata, C. coccoides and $F$. verticillioides. The implication could mean $C$. esculenta var. esculenta may resist new strains or race of the pathogenic fungi that can attack the genome of this cocoyam variety should there be an epidemic (Agrios, 2005). The fungus Fusarium verticillioides that is normally associated with or causes a disease in rice called 'bakanae' must have crossed contaminate cocoyam in the process). Because most of the farmers of cocoyam in Plateau state practice mixed cropping, they always plant and store cocoyam alongside rice. This present study is at slight variance with the results of Chiejina and Ugwuja (2013), Mehrotra and Aggarawal (2003) who reported in Nsukka and India that the two varieties varied in terms of their susceptibility and incidence of Phytopthora leaf-blight differently and equally respectively. These slight variations also could be attributed to differences in the aspects of the studies, disease and environment; whereas their studies centered on the field (field pathology), Nsukka and India, Phytophthora leaf blight, this present studies centered on post harvest (storage pathology), Plateau state, in Nigeria and fungi species respectively.

\section{CONCLUSION}

The study reveal that nine different fungal species were involve in the deterioration of the two varieties of cocoyam corms and cormels under study with varying degree of virulence. The pathogenicity of these fungi isolates from the present study suggests that they are capable of initiating rot thereby causing loss of cocoyam corms and cormels during storage. Based on the results, control measures should be embarked upon in subsequent work in order to control the disease and boost cocoyam production.

\section{REFERRENCE}

Agrios, G. N. 2005. Plant Pathology, 5th ed., Academic Press, New York. 520-530.

Aggarawal. A., K. L. Narula, G. Kaur and R. S. Mehrotra. 1990. Phytophthora colocasia Racib., - Its Taxonomy, Physiology, Pathology and Control. In: Perspectives in Mycological Research 2, S. K. Hasija and K.S (Eds.) Today and Tomorrows Printer, New Delhi. 105-134.

Aguegui, A. C. A. Fatukun and S. K. Haln. 1992. Protein analysis of ten cocoyam, Xanthosoma, sagittifolium (L) Schott and Colocasia esculenta (L) Schott, Root crops for food security in Africa, proceedings of the $5^{\text {th }}$ Triennial symposium, Kampala, Uganda. pp.348.

Anukworji, C. A., R. R. Putheti and R. N. Okigbo2012. Isolation of fungi causing rot of cocoyam (Colocasia esculenta (L.) Schott) and control with plant extracts:(Allium sativum, L., Garcinia kola, heckel., Azadirachta indica, L. and Carica papaya, L.). Glo. Adv. Res. J. Agric. Sci, 1, 33-47.

Brunt, J., D. Hunter and C. Delp. 2001. A Bibliography of Taro Leaf Blight. Secretariat of the Pacific Community (SPC) AusAID taro genetic resources: conservation and utilization. Noumea, New Caledonia. 93pp.

Brooks, F. E. 2000. Cultivar Resistance to Taro Leaf Blight Disease in American Samoa, American Samoa Technical Report, 34, 49-58.

Domsch, K. H., W. Gams and T. H. Anderson. 1980. Compendium of soil fungi, 2 Vols. London: Academic press.

Chiejina. N. V and F. N. Ugwuja. 2013. Incidence of Phytophthora Leaf-Blight disease of cocoyam in Nsukka area of South Eastern Nigeria. J. of So? Res. 4 (1): 21-24.

Clement, Z. k and E. S. Voros. 1974. Methods in pathology. 
Elsvier Scientific Publishing Co., Amsterdam, London 220-288pp.

Ellis, D. H. 2005b. Systemic Zygomycetes-Mucormycosis. In Topley and Wilson's Microbiology and Microbial Infections: Medical Mycology, 10th edition, pp33-36.

Ellis, D. H., D. Stephen, A. Helen, H. Rosemary and B. Robyn. 2007. Descriptions of Medical Fungi. $2^{\text {nd }}$ ed. Hodder Arnold London, Australia. 187 pp.

Eze, C. C. and E. C. Okorji. 2003. Cocoyam production by women farmers under improved and local technology in Imo state, Nigeria, African J. Sciences 5(1): 113-116.http://www.fao.org.

Eze, C. C, and J. N. C. Maduewesi. 1990. Relationships of traditional Methods to the magnitude of storage losses of cocoyam (Colocasia esculenta (L) Schott). Nig. J. Plant Protection 13:26 34.

IITA. 1993. Crop Improvement Division/Tuber root Improvement Program Archival Reports (1989 - 1993). Part III yam (Dioscorea spp). Ibadan, Nigeria, pp. 20-85.

Maduewesi, J. N. and C. Onyike. 1981. Fungal Rotting of Cocoyam in Storage of Nigeria. In: Terry Oduro and Caveness (eds), Proceedings of the $1^{\text {st }}$ Triennial Root crop Symposium of the INSTR. AB. Sept. 1990. Ibadan, Nigeria. pp 235-238.

Mehrotra, R. S. and A. Aggarawal. 2003. Plant Pathology, 2nd ed., Tata McGraw-Hill. New Delhi, New York: 846pp

Misra, R. S. 1993. Tropical Tuber Crops: Problems, Prospects and Future Strategies, Oxford and IBH, 380-388.
Offei, S. K., I. K. Asante and E. Y. Danquah. 2004. Genetic Structure of Seventy cocoyam Accessions In Ghana Based on RAPD. Hereditas 140:123 128.

Olurinola P. F., J. O. Ehimmadu and J. J. Bonire. 1992. Antifungal Activity of n-Tributylin Acetate against some common yam rots fungi. Applied and Envriomental Microbiol. 58(2): 758-760.

Olutola, P. O., O. Famurewa and H. G. Somtag. 2000. An introduction to general microbiology: A practical Approach. Bolabary publications, Nigeria, $124 \mathrm{pp}$.

Onuegbu, B. A. 1999. Composition of four cocoyam cultivars and their tolerance to corm rot. Tropical Sci. 39: 136-139.

Onwueme, I. C. and W. B. Charles. 1994. Tropical root and tuber crops-production, perspectives and future prospects. FAO plant production and protection paper $126 \mathrm{pp}$.

Onwueme, I. C. 1999. Taro cultivation in Asia and the Pacifi. Food and Agriculture Organization of the United Nations, Regional Office for Asia \& the Pacific, RAP Publication No.16. Bangkok, Thailand. 50pp.

Samson, R. A., E. S. Hoekstra, J. C. Frisvad and 0. Filtenborg. 1995. Introduction to food-borne fungi. Central bureau voor Schimmel cultures, P.O.Box 273, 3740 AG BAARN, The Netherlands.

Uguanyi J. $O$ and J. A. Obeta. 1996. Fungi associated with storage rots of cocoyams (Colocasia spp) in Nsuka, Nigeria, Department of microbiology University of Nigeria Nsuka Mycopathologia, 134(1), 21-25.

Zuhair, M and D. G. Hunter. 2000. Taro cultivation and use in the maldwes. IPGR Session 12th Symp. Of IATRC, TSUKUBA. Japan. 